\title{
MONITORING GROUND WATER POLLUTION IN (CONSTANTA) PECINEAGA ZONE
}

\author{
ARAM SULEIMAN \\ $\mathrm{Ph}$.D. student \\ University of Agronomical Sciences and Veterinary Medicine Doctorate school in Bucharest. \\ Bucharest, Romania
}

\begin{abstract}
The Purpose of Monitoring Ground water pollution to Assess the status of water quality that changes spatially and temporally. The objectives of the study were to monitor (Nitrate, Ammonium, $\mathrm{pH}$, Electrical Conductivity, Oxygen dissolved) in Constanta, Pecineaga zone. The samples were taken from 12 different wells in Pecineaga zone, in the same day, the samples were analyzed in the Sites with a probe analyzer for estimating water quality. The results were compared with Romanian Directive and showed that the concentrations of nitrate and Ammonium in ground water in Pecineaga zone for most of the samples are bigger than the maximum levels in Romanian directives, and $41.67 \%$ were included in the Class IV, and $58.33 \%$ were included in the Class $\mathrm{V}$ for the oxygen dissolved in water in Romanian directives, the acidity of water $\mathrm{pH}$ for all the samples included between the maximum value of $\mathrm{pH} 9.5$ and the minimum value of $\mathrm{pH} 6.5$, electrical conductivity of $60 \%$ from samples were more than the maximum admissible value in Romanian directives.
\end{abstract}

Keywords: Monitoring, pollution, Nitrate, Ammonium, water acidity, Electrical conductivity

\section{INTRODUCTION}

\section{Water Pollution}

A widely used definition of pollution is the introduction by man into the environment of substances or energy reliable to cause hazards to human health, harm to living resources and ecological systems. Damage to structures or amenity, or interference with legitimate uses if the environment "Holdgate, (1979)". Some water pollutants which become extremely toxic in high concentrations are, however, needed in trace amounts. Copper, zinc, manganese, boron and phosphorus, for example, can be toxic or may otherwise adversely affect aquatic life when present above certain concentrations, although their presence in low amounts is essential to support and maintain functions in aquatic ecosystems. The same is true for certain elements with respect to drinking water. Selenium, for example, is essential for humans but becomes harmful or even toxic when its concentration exceeds a certain level. The concentrations above which water pollutants adversely affect a particular water use may differ widely. Water quality requirements, expressed as water quality criteria and objectives, are use-specific or are targeted to the protection of the most sensitive water use among a number of existing or planned uses within a catchment. Approaches to water pollution control initially focused on the fixed emissions approach and the water quality criteria and objectives approach. Emphasis is now shifting to integrated approaches. The introduction of holistic concepts of water management, including the ecosystem approach, has led to the recognition that the use of water quality objectives, the setting of emission limits on the basis of best available technology and the use of best available practices, are integral instruments of prevention, control and reduction of water pollution. These approaches should be applied in an action-orientated way. A further development in environmental management is the integrated approach to air, soil, food and water pollution control using multimedia assessments of human exposure pathways "R. Hemler; I. Hespanhol, (1997); ICWE, (1992); UNCED, (1992)"

\section{Nitrate pollution}

Leaching of $\mathrm{NH}_{4}^{+}$is generally not important, since it is strongly adsorbed by soil, except for sands and soils having low retention (cation exchange) capacities. The $\mathrm{NO}^{-}$ion is readily leached deeper into the soil profile, below the bottom of the root zone, and may eventually enter ground water supplies. Ground water flows within permeable 


\section{International Journal of Engineering Applied Sciences and Technology, 2019 \\ Vol. 4, Issue 2, ISSN No. 2455-2143, Pages 24-33 \\ Published Online June 2019 in IJEAST (http://www.ijeast.com)}

geologic formations called aquifers. Aquifers are natural zones beneath the earth's surface and often yield economically important amounts of water. The $\mathrm{N}$ often observed in streams that drain agricultural land primarily comes from ground water contributions (including tile-drainage effluent) to stream flow, rather than from overland-flow runoff of $\mathrm{N}_{\mathrm{r}}$. In a very simple system, water and dissolved $\mathrm{NO}_{3}{ }^{-}$percolate below the root zone and through the intermediate vadose zone to an aquifer. From there, these waters can recharge deeper aquifers or discharge to streams or water bodies. During discharge events, the ground water and its $\mathrm{NO}_{3}{ }^{-}$load will include shallow interflow (sometimes referred to as subsurface runoff). $\mathrm{NO}_{3}{ }^{-}$and $\mathrm{NO}_{2}{ }^{-}$ions are both highly soluble and susceptible to transport in water. The $\mathrm{NO}_{2}{ }^{-}$ion is seldom a major $\mathrm{N}_{\mathrm{r}}$ form because it is rapidly transformed to $\mathrm{NO}_{3}^{-}$. During a majority of the time, deeper ground-water base flow provides the major contribution of $\mathrm{NO}_{3}{ }^{-}$as it rejoins surface-water flows. Deeper aquifers can be recharged by, or discharge to, streams or water bodies. Aquifers are subdivided based upon geology. A meaningful division, from the perspective of ground water quality, is between confined and unconfined aquifers. Confined aquifers are separated from the Earth's surface by flow-impeding layers that, depending upon the degree of flow impedance, are referred to as aquicludes or aquitards. Unconfined aquifers are not separated from the Earth's surface by a flowimpeding layer, and are therefore in contact with the atmosphere through the unsaturated zone. Aquifer systems are often complex. To minimize the amount of NO3- that may enter groundwater, it is necessary to understand the aquifer system and then to identify and apply improved $\mathrm{N}$ management practices to the recharge area of the aquifer. Structure of the aquifer system and subsequent flow patterns affect $\mathrm{NO}_{3}{ }^{-}$ dilution, transport, and removal "Jorge A. Delgado; Ronald F. Follet, (2010)”. Groundwater can rejoin the surface water down-slope and adjacent to a perennial stream, often along a riparian zone. During storms or wet periods, the water table can rise rapidly to intersect the land surface at some distance from the stream and discharge of ground water to the soil surface results. The system can be dynamic, with water table levels, extent of the saturated zone, and flow directions changing substantially and rapidly with precipitation. As the ground water and its dissolved $\mathrm{NO}_{3}{ }^{-}$move into the more biologically and chemically active soil zones, the $\mathrm{NO}^{-}$becomes available for uptake by riparian vegetation. Also, if $\mathrm{O}_{2}$ level become limited, activation of biological and chemical soil regimes denitrifies the $\mathrm{NO}^{-}$form of $\mathrm{N}$ to the gaseous $\mathrm{N}_{2}$ form "J. L. Hatfield; R. F. Follett,
(2008) ". In addition to degradation of drinking water, high nitrate levels in groundwater can also negatively affect the health of streams and rivers. Many groundwater aquifers flow into surface water streams, where they deliver their nitrate. This nitrate acts as a nitrogen fertilizer source in streams. Nitrogen in streams can lead to excessive aquatic plant and algal growth. This growth is part of a process called eutrophication, which occurs when water is overenriched with nutrients. The resulting algal blooms block sunlight from penetrating the surface, thus contributing to oxygen deficient waters. Low oxygen levels in the water create a degraded and eventually intolerable habitat for fish.

Without careful and precise application and timing of nitrogen fertilizers, nitrate can leach through the soil into the groundwater. Over irrigation increases nitrate leaching, reducing the efficiency of nitrogen fertilization and increasing the nitrate level in groundwater. Nitrate leaching is more likely where shallow-rooted crops such as onions and potatoes are grown on coarse-textured soil. These crops require careful watering as they have difficulty reaching deep into the soil for nutrients leached below their shallow root zone. “K.M. Foley, et al. (2012)”

\section{Monitoring}

Monitoring is defined by the International Organization for Standardization (ISO) as: "the programmed process of sampling, measurement and subsequent recording or signaling, or both, of various water characteristics, often with the aim of assessing conformity to specified objectives". This general definition can be differentiated into three types of monitoring activities that distinguish between longterm, short-term and continuous monitoring programmers as follows:

- Monitoring is the long-term, standardized measurement and observation of the aquatic environment in order to define status and trends.

- Surveys are finite duration, intensive programmers to measure and observe the quality of the aquatic environment for a specific purpose.

- Surveillance is continuous, specific measurement and observation for the purpose of water quality management and operational activities.

\section{“B. Jamie; B. Richard, (1996)”.}

\section{Environmental monitoring}

Environmental monitoring is the observation and study of the environment. In scientific terms, we wish to collect data from which we can derive 
knowledge. Thus, environmental monitoring has its role defined in the first three steps of the staircase and is rooted in the scientific method. Objective observations produce sound data, which in turn produce valuable information. Information-derived knowledge usually leads to an enhanced understanding of the problem/situation, which improves the chances of making informed decisions. "Janick Artiola, et al., ( 2004)".

\section{Water quality monitoring}

Water influences natural systems and human activities in the context of a river basin. In turn, natural water systems are shaped by their physical basins, human use, environmental changes and climate systems. As the Earth's population and the resulting anthropogenic footprint and impact on climate increase, the need to maintain and protect freshwater resources gains importance for sustainable development, balancing social needs with economic development and environmental stewardship " $C$. Bordan; D. Roy, (2015)’”.

\section{GROUNDWATER MONITORING SYSTEM}

Table 1. Technical specifications:
Monitoring groundwater is performed to characterize groundwater quantity and quality in order to address issues regarding proper assessment and protection of groundwater resources. Types of water resource issues that groundwater data are used for include aquifer characterization (quality and quantity), water budgets, conjunctive management, safe yield of groundwater abstraction, salinity intrusions, water logging, water quality contamination characterization, aquifer recharge zone delineation, aquifer-recovery-storage (ARS) projects, policy design and evaluation, and research and studies. " $C$. Bordan; D. Roy,( 2015)".

\section{MATERIALS AND METHOD}

The research was conducted in (Pecineaga) Constanta; the samples were taken from 12 different wells in Pecineaga, in the same day, the samples were analyzed in the Sites, with a probe analyzer for estimating water quality (Model 4A), The equipment is used in situ for determination of water quality characteristics: temperature, $\mathrm{pH}$ (concentration of hydrogen ions), specific conductivity (indicates the amount of dissolved salts), the amount of oxygen dissolved in water, the concentration of ammonium ions in water, the concentration of nitrate ions in water and chlorophyll.

\begin{tabular}{|l|l|l|l|}
\hline Parameter & Measuring range & Accuracy & Resolution \\
\hline Temperature & -5 la $50^{\circ} \mathrm{C}$ & $\pm 0,1{ }^{\circ} \mathrm{C}$ & $0,01{ }^{\circ} \mathrm{C}$ \\
\hline Electrical conductivity & 0 la $100 \mathrm{mS} / \mathrm{cm}$ & $\begin{array}{l} \pm 1 \% \\
\pm 0,001 \mathrm{mS} / \mathrm{cm}\end{array}$ & 4 digits \\
\hline $\mathrm{pH}$ & 0 la $14 \mathrm{units}$ & $\pm 0,2$ unităţi & $0,01 \mathrm{units}$ \\
\hline Dissolved Oxygen & 0 la $20 \mathrm{mg} / \mathrm{l}$ & $\pm 0,2 \mathrm{mg} / \mathrm{l}$ & $0,01 \mathrm{mg} / \mathrm{l}$ \\
\hline Ammonium & 0 la $100 \mathrm{mg} / \mathrm{l}-\mathrm{N}$ & $\begin{array}{l}\text { Bigger than } \pm 5 \% \\
\text { Or } \pm 2 \mathrm{mg} / \mathrm{l}-\mathrm{N}\end{array}$ & $0,01 \mathrm{mg} / \mathrm{l}-\mathrm{N}$ \\
\hline Nitrate & 0 la $100 \mathrm{mg} / \mathrm{l}-\mathrm{N}$ & $\begin{array}{l}\text { Bigger than } \pm 5 \% \\
\text { Or } \pm 2 \mathrm{mg} / \mathrm{l}-\mathrm{N}\end{array}$ & $0,01 \mathrm{mg} / \mathrm{l}-\mathrm{N}$ \\
\hline Clorofill & & $\pm 3,5 \mu \mathrm{g} / \mathrm{l}$ & $0,01 \mu \mathrm{g} / \mathrm{l}$ \\
\hline
\end{tabular}


International Journal of Engineering Applied Sciences and Technology, 2019

Vol. 4, Issue 2, ISSN No. 2455-2143, Pages 24-33

Published Online June 2019 in IJEAST (http://www.ijeast.com)

Water level

0 la $100 \mathrm{~m}$

$\pm 0,3 \mathrm{~m}$

$0,1 \mathrm{~m}$

Results

Table 2. Grade of pollution with different chemical substances for the sources of water in Constanta (Pecineaga)

\begin{tabular}{|l|l|l|l|l|l|l|l|l|l|}
\hline $\mathrm{Nb}$ & $\begin{array}{l}\text { Altitude } \\
\mathrm{m}\end{array}$ & $\begin{array}{l}\text { Temperature } \\
\mathrm{C}^{\mathrm{o}}\end{array}$ & $\begin{array}{l}\mathrm{EC} \\
\mathrm{mmhos} / \mathrm{cm}\end{array}$ & $\begin{array}{l}\mathrm{O} \\
\mathrm{mg} / 1\end{array}$ & $\begin{array}{l}\mathrm{NH}_{4} \\
\mathrm{Mb} / 1\end{array}$ & $\begin{array}{l}\mathrm{NO}_{3} \\
\mathrm{Mg} / 1\end{array}$ & $\mathrm{pH}$ & $\begin{array}{l}\text { Chlorophyll } \\
\mathrm{Mg} / 1\end{array}$ & $\begin{array}{l}\text { Depth of } \\
\text { sample } \\
\mathrm{m}\end{array}$ \\
\hline 1 & 49 & 16.05 & 1.260 & 4.65 & 0.55 & 14.65 & 7.78 & 0.00 & Headrace \\
\hline 2 & 46 & 13.41 & 2.594 & 4.10 & 0.53 & $>100$ & 7.60 & 9.32 & 4 \\
\hline 3 & 46 & 12.986 & 3.202 & 3.962 & 0.58 & $>100$ & 7.58 & 7.88 & 3.80 \\
\hline 4 & 50 & 13.33 & 1.822 & 3.88 & 0.53 & $>100$ & 7.70 & 0.62 & 3.5 \\
\hline 5 & 49 & 13.248 & 2.032 & 3.02 & 0.49 & $>100$ & 7.50 & 0.58 & 3 \\
\hline 6 & 47 & 13.62 & 1.723 & 3.456 & 0.62 & $>100$ & 7.18 & 0.16 & 3.5 \\
\hline 7 & 50 & 13.11 & 1.904 & 3.207 & 0.58 & $>100$ & 7.54 & 0.11 & 4 \\
\hline 8 & 43 & 14.263 & 2.657 & 4.53 & 0.86 & $>100$ & 7.20 & 0.23 & 3.5 \\
\hline 9 & 43 & 13.653 & 2.856 & 4.43 & 1.01 & $>100$ & 7.77 & 0.12 & 4 \\
\hline 10 & 49 & 14.013 & 2.328 & 3.98 & 0.83 & $>100$ & 7.80 & 0.26 & 4 \\
\hline 11 & 50 & 14.23 & 2.430 & 3.73 & 0.62 & $>100$ & 7.3 & 0.32 & 4 \\
\hline 12 & 39 & 13.93 & 1.236 & 4.93 & 0.57 & $>100$ & 7.12 & 0.00 & 14 \\
\hline
\end{tabular}

The grade of pollution with Nitrate, Ammonium, the total amount of dissolved salts measured by electrical conductivity (EC), and Oxygen dissolved in water, were determined in the base of (Romanian directive, LEGE nr.458 din 8 iulie 2002).

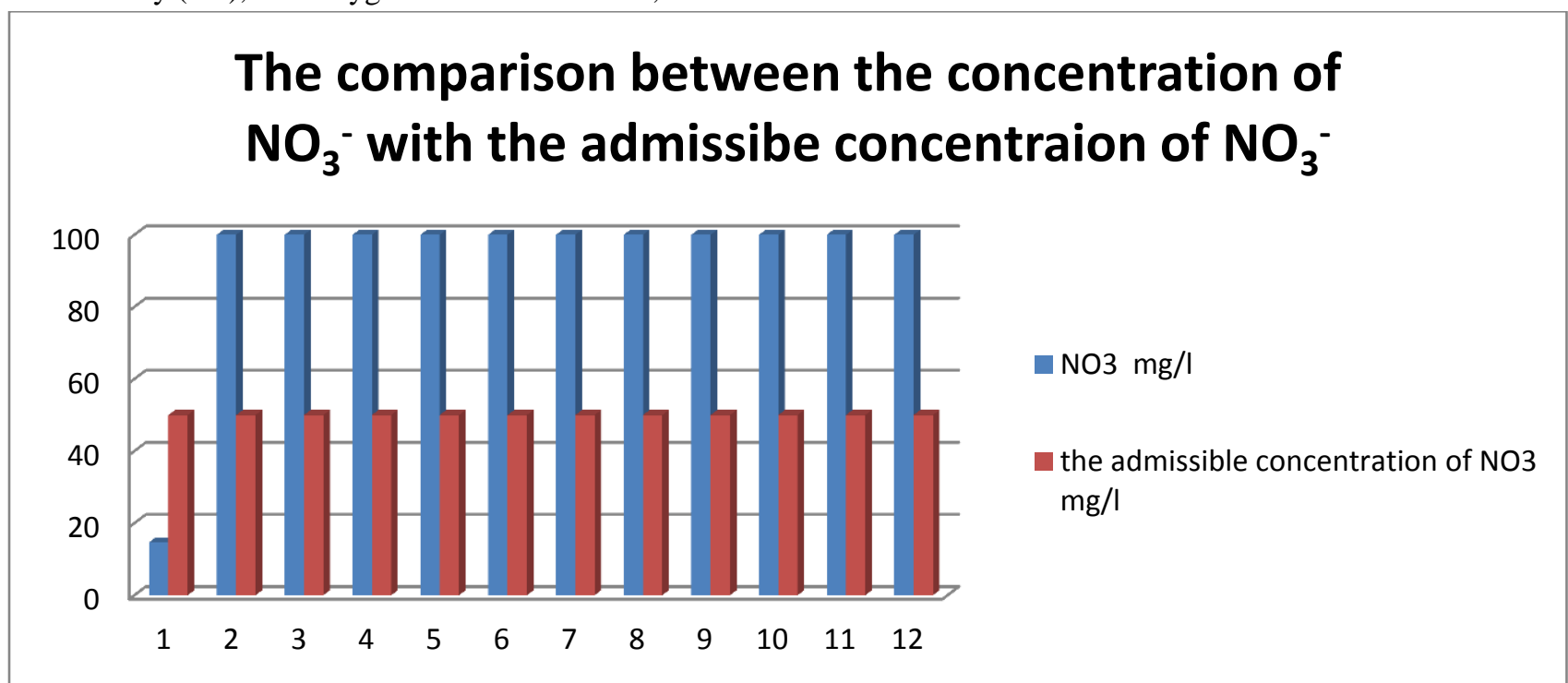

Figure 1 the comparison between the concentration of nitrate in ground water of Pecineaga and the admissible concentration of nitrate 
From the table 2 and figure 1 we observe that the concentration of nitrate in wells number $2,3,4,5,6,7,8,9,10,11,12$, is $>100 \mathrm{mg} / \mathrm{l}$ and it is bigger than the maximum level of concentration of nitrate $50 \mathrm{mg} / \mathrm{l}$ in Romanian directives, and these concentrations are bigger than two times more than the admissible concentration of nitrate, as well as the maximum level of nitrate in drinking water for human is $45 \mathrm{mg} / \mathrm{l}$ and for animals $100 \mathrm{mg} / \mathrm{l}$ "M. Domitru et al., (2013)"

\section{The percentage of concentration ranges of nitrate}

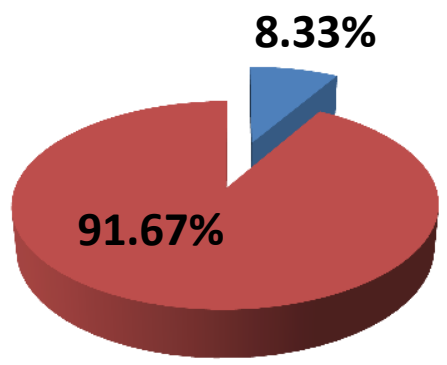

$$
\begin{aligned}
& 0-25 \mathrm{mg} / \mathrm{l} \\
& >100 \mathrm{mg} / \mathrm{l} \\
& 50-100 \mathrm{mg} / \mathrm{l} \\
& 25-50 \mathrm{mg} / \mathrm{l}
\end{aligned}
$$

Figure 2 the percentage of concentration ranges of nitrate in ground water of Pecineaga.

\section{Ammonium:}

Figure 3. comparison between the concentration of ammonium in ground water of Pecineaga and admissible

\section{Concentration of $\mathrm{NH}_{4}{ }^{+}$with the admissible concentration of $\mathrm{NH}_{4}^{+}$}

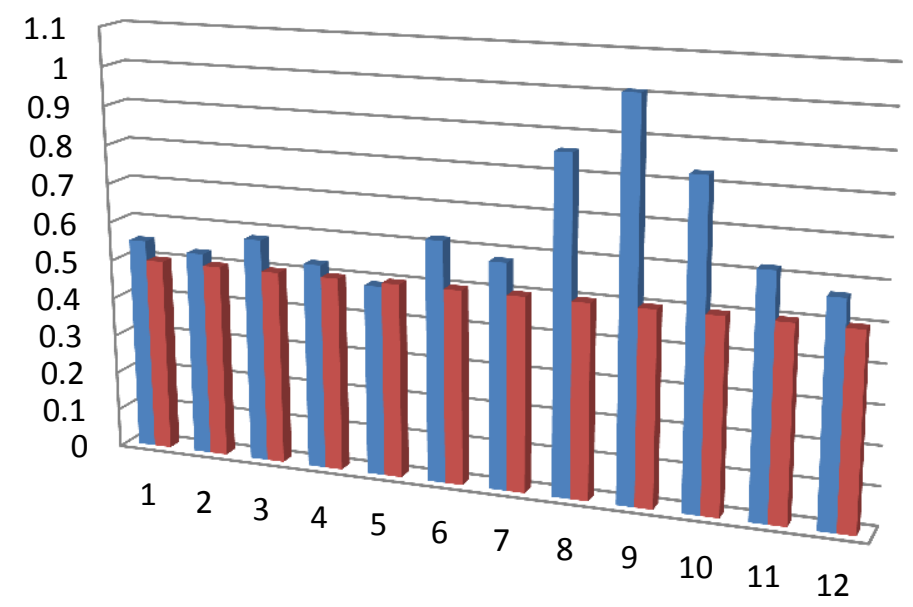

$\mathrm{NH} 4 \mathrm{mg} / \mathrm{l}$

the admissible concentration of $\mathrm{NH} 4 \mathrm{mg} / \mathrm{l}$

\section{concentration}

From table 2 and figure 3 we observe that the concentration of Ammonium in well number 1
,2,3,4,6,7,8,9,10,11 are bigger than the maximum level of concentration of ammonium $0.5 \mathrm{mg} / \mathrm{l}$ in 
Romanian directives, concentration of Ammonium in well number 9 is $1.01 \mathrm{mg} / \mathrm{l}$ bigger two times more and the concentration of ammonium in well number 5 is 0.49 slightly less than the maximum level of concentration of ammonium $0.5 \mathrm{mg} / \mathrm{l}$ in Romanian directives. From these results we can observe that the well number 5 is not polluted with ammonium and it is usable for human drinking if we take just ammonium Concentration in the consideration than the maximum level of concentration of ammonium $0.5 \mathrm{mg} / \mathrm{l}$ in Romanian directives. regardless other pollutants, with difference $0.01 \mathrm{mg} / 1$ less than the maximum level of ammonium concentration to be considered as a polluted water with ammonium that should be in consideration to be aware about it as the wells that are polluted with ammonium

\section{percentage of wells with the concentration of Ammonium}

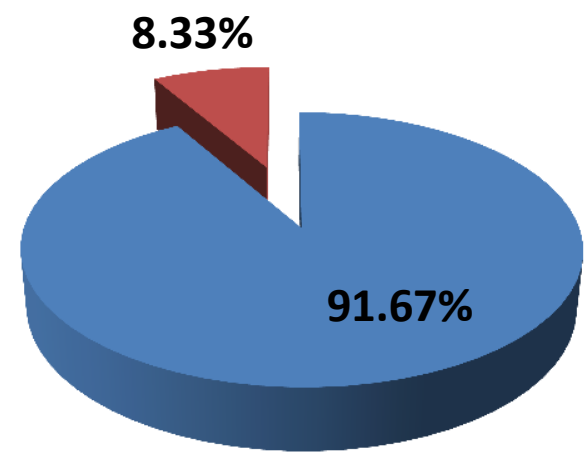

Figure 4. the percentage of ammonium concentration in ground water of Pecineaga

Electrical conductivity

\section{Electrical conductivity EC with admissible EC}

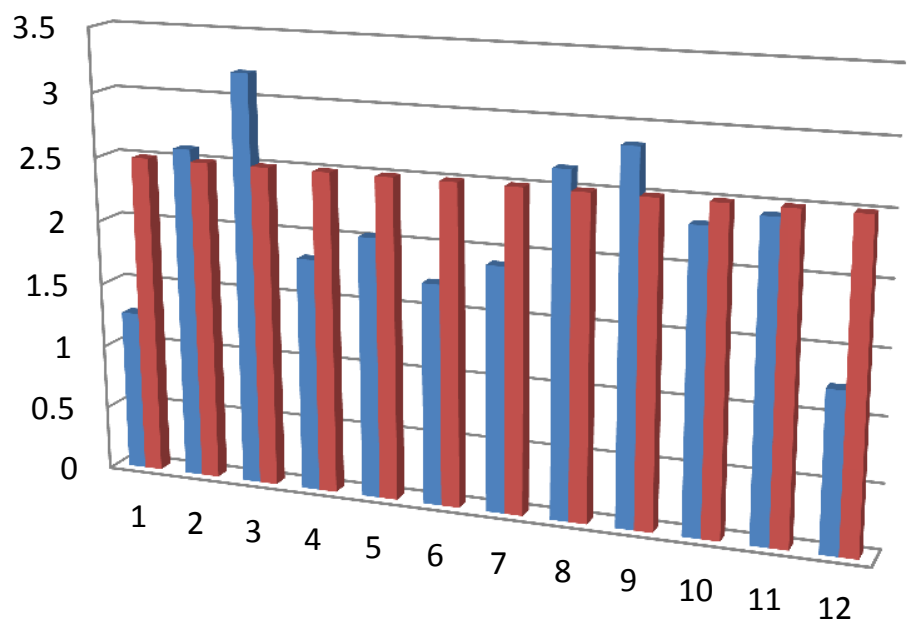

EC mmhos/cm

the admissible EC mmhos/cm 
Figure 5 comparison between Electrical conductivity EC in ground water of Pecineaga with admissible EC

From table 2 and figure 5, we observe that the electrical conductivity EC that refers to the total dissolved salts in water for the wells number 2,3,8,9 with the values of EC, 2.594, 3.202, 2.657, 2.856, $\mathrm{mmhos} / \mathrm{cm}$ respectively are bigger than the maximum admissible value of EC $2.5 \mathrm{mmhos} / \mathrm{cm}$ in Romanian

These results refer that the wells number 2,3,8,9 are polluted with dissolved salts in water, and the wells directives, and the electrical conductivity EC for the wells number $1,4,5,6,7,10,11,12$ with the values of EC, $1.26,1.822,2,032,1.723,1.904,2.328,2.43$, $1.236 \mathrm{mmhos} / \mathrm{cm}$ respectively are less than the maximum admissible value of EC $2.5 \mathrm{mmhos} / \mathrm{cm}$ in Romanian directives.

number $1,4,5,6,7,10,11,12$, are not polluted with dissolved salts in water.

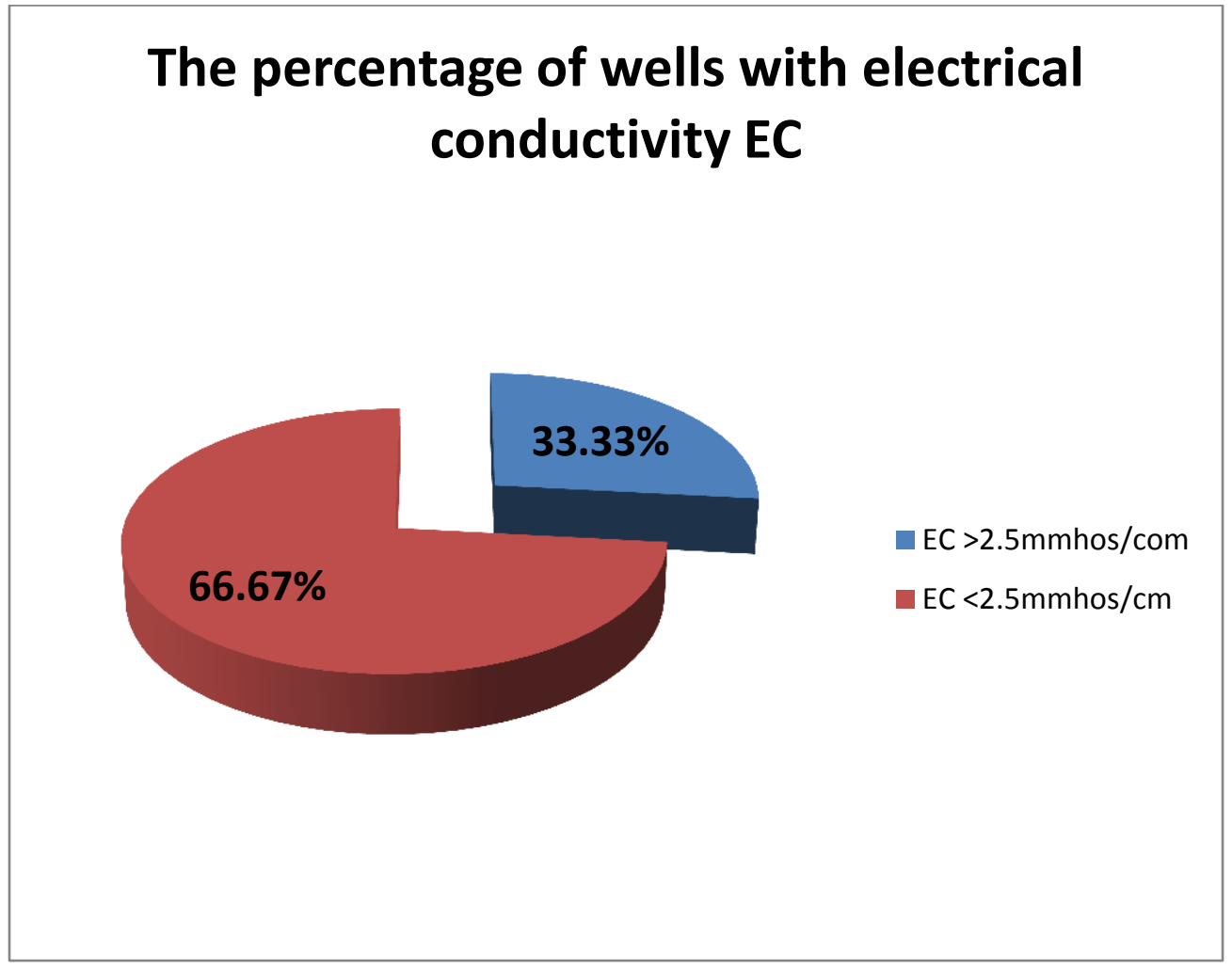

Figure 6. the percentage of Electrical conductivity ranges in ground water of Pecineaga.

The Oxygen dissolved in water:

Table 3. The Classification of the Oxygen dissolved in water for each well

\begin{tabular}{|c|c|c|c|c|c|c|c|c|c|c|c|c|c|}
\hline & \multirow[b]{2}{*}{ limits } & \multicolumn{12}{|c|}{$\mathrm{Nb}$ of wall } \\
\hline & & 1 & 2 & 3 & 4 & 5 & 6 & 7 & 8 & 9 & 10 & 11 & 12 \\
\hline class I & $>7 \mathrm{mg} / \mathrm{l}$ & & & & & & & & & & & & \\
\hline $\begin{array}{l}\text { class } \\
\text { II }\end{array}$ & $\begin{array}{l}6-6.9 \\
\mathrm{mg} / 1\end{array}$ & & & & & & & & & & & & \\
\hline $\begin{array}{l}\text { class } \\
\text { III }\end{array}$ & $\begin{array}{l}5-5.9 \\
\mathrm{mg} / 1\end{array}$ & & & & & & & & & & & & \\
\hline $\begin{array}{l}\text { class } \\
\text { Iv }\end{array}$ & $\begin{array}{l}4-4.9 \\
\mathrm{mg} / \mathrm{l}\end{array}$ & 4.65 & 4.1 & & & & & & 4.53 & 4.43 & & & 4.93 \\
\hline $\begin{array}{l}\text { class } \\
\mathrm{V}\end{array}$ & $<4 \mathrm{mg} / \mathrm{l}$ & & & 3.962 & 3.88 & 3.02 & 3.456 & 3.207 & & & 3.98 & 3.73 & \\
\hline
\end{tabular}


From table 3 we observe that the classification of Oxygen dissolved in water the wells number $1,2,8,9,12$, have the concentration of oxygen dissolved in water $4.65,4.1,4.53,4.43,4.93 \mathrm{mg} / \mathrm{l}$ respectively considered in the range of Class IV between 4-4.9 $\mathrm{mg} / \mathrm{l}$, and the wells number
$3,4,5,6,7,10,11$ have the concentration of oxygen dissolved in water $3.962,3.88,3.02,3.456,3.207$, $3.98,3.73 \mathrm{mg} / \mathrm{l}$ respectively are considered in the Class V with the range of concentration less $<4 \mathrm{mg} / \mathrm{l}$.

\section{Percentage of wells with the classification of dissolved Oxygen}

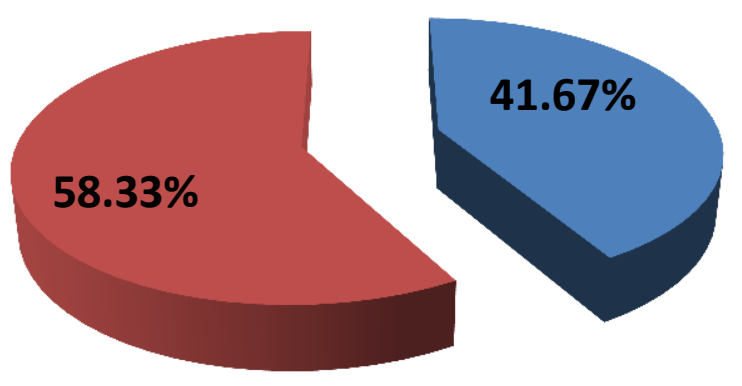

class 4

class 5

Figure 7. the percentage of oxygen dissolved in water classification in ground water of Pecineaga.

Water acidity:

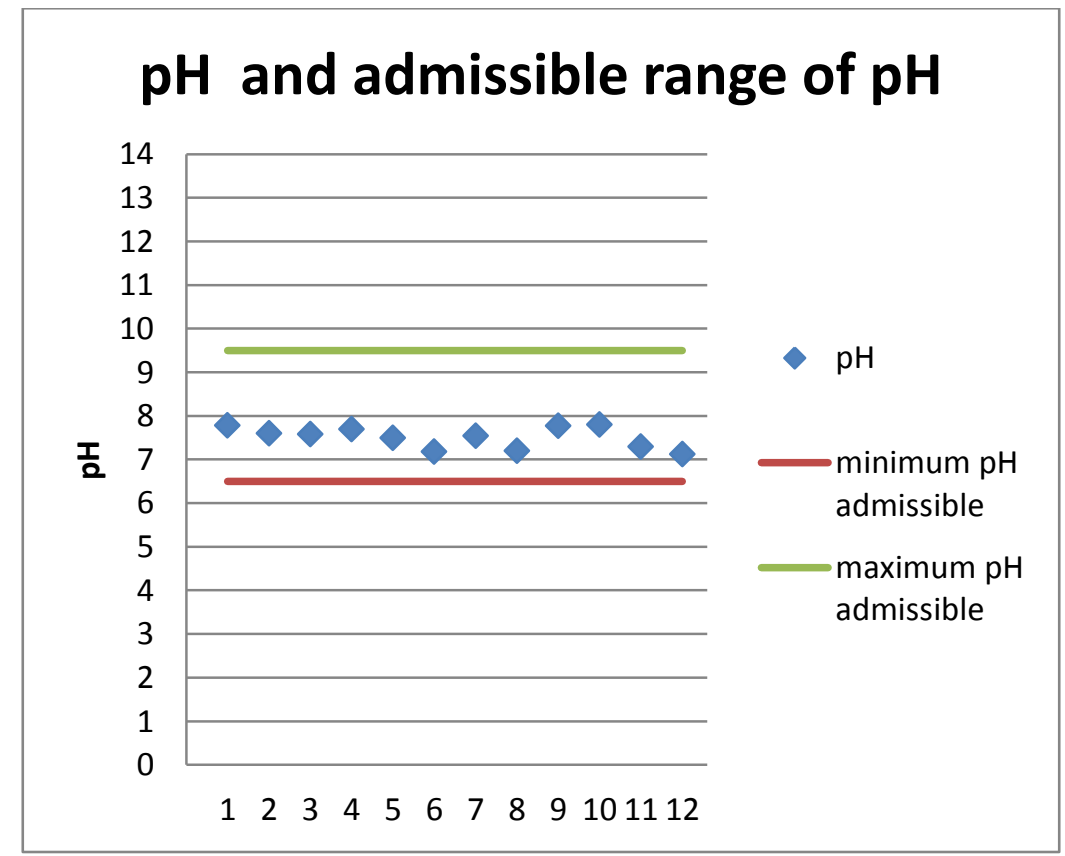

Figure 8. the values of $\mathrm{pH}$ in ground water of Pecineaga and admissible range of pH 


\section{International Journal of Engineering Applied Sciences and Technology, 2019 \\ Vol. 4, Issue 2, ISSN No. 2455-2143, Pages 24-33 \\ Published Online June 2019 in IJEAST (http://www.ijeast.com)}

We observe from table 2 and figure 8 that the acidity of water $(\mathrm{pH})$ for all the wells (total 12) have the values of $\mathrm{pH}$ included between the maximum value of $\mathrm{pH} 9.5$ and the minimum value of $\mathrm{pH}$ 6.5. in Romanian directives.

The wells number $6,8,11$, have natural to slightly alkaline $\mathrm{pH}$, and the wells number 1,2,3,4,5,7,9,10,11 have slightly alkaline $\mathrm{pH}$.

\section{CONCLUSION}

\section{Nitrate}

The concentration of nitrate in ground water in Pecineaga for most of the samples is $>100 \mathrm{mg} / \mathrm{l}$ and it is bigger than the maximum level of concentration of nitrate $(50 \mathrm{mg} / \mathrm{l})$ in Romanian directives, and these concentrations are bigger than two times more than the admissible concentration of nitrate, as well as the maximum level of nitrate in drinking water for human is $45 \mathrm{mg} / \mathrm{l}$ and for animals $100 \mathrm{mg} / \mathrm{l}$. The accumulation of nitrate in ground water in these wells could be from the applications of nitrogen fertilizers, from mineralization of organic matter from sewage sludge and manure.

\section{Ammonium:}

The concentration of Ammonium in ground water in Pecineaga for most of the samples is bigger than the maximum level of concentration of ammonium (0.5 $\mathrm{mg} / \mathrm{l}$ in Romanian directives).

The accumulation of ammonium in ground water is difficult than nitrate because of its positive charge that can be attracted to the clay minerals in soil with negative charges in these wells the pollution with ammonium ion could be from the applications of nitrogen fertilizers or from waste water, and mineralization of organic matter.

\section{Electrical conductivity}

The electrical conductivity EC that refers to the total dissolved salts in water for more than $60 \%$ of the samples were taken from Pecineaga are bigger than the maximum admissible value of EC 2.5 $\mathrm{mmhos} / \mathrm{cm}$ in Romanian directives.

\section{The Oxygen dissolved in water:}

The percentage $41.67 \%$ (5 wells from the total 12) were included in the Class IV for the oxygen dissolved in water between the range 4-4.9 $\mathrm{mg} / \mathrm{l}$ in Romanian directive and the percentage $58.33 \%$ (7 wells from the total 12) were included in the Class V for the oxygen dissolved in water are $<4 \mathrm{mg} / \mathrm{l}$ in Romanian directive. Class IV and Class V represent the limits 2-5 times lower than the reference objectives and reflect the anthropogenic effects.

\section{Water acidity:}

The acidity of water $(\mathrm{pH})$ for all the wells (total 12) have the values of $\mathrm{pH}$ included between the maximum value of $\mathrm{pH} 9.5$ and the minimum value of pH 6.5. in Romanian directives.

\section{REFERENCES}

1) Brusseau, (2004). Environmental monitoring and characterization, Elsevier Science \& Technology Books, ISBN: 0120644770,pp:1-8.11,12,29,30,86

2) Carter Borden ; Dimple Roy, (2015). Water quality monitoring system design, Published by the International Institute for Sustainable Development.

3) Helmer Richard, Ivanildo Hospanhol,( 1997). Water pollution control Agide to the use of water quality management princibles,WHO/UNEP, ISBN 0-20378578-9

4) Holdgate,M. W. (1979). aprespective of environment pollution. Cambridge university press, Cambridge.

5) International Converence on Water and the Environment ICWE,(1992). Development issues for th 21th century ,26-31 january, 1992. Dublin, Irland.

6) Jamie Bartram and Richard Ballance, (1996). Water Quality Monitoring - A Practical Guide to the Design and Implementation of Freshwater Quality Studies and Monitoring Programmes Published on behalf of United Nations Environment Programme and the World Health Organization (C) 1996 UNEP/WHO ,ISBN 0419223207 (Hbk) 0419217304 (Pbk)

7) Janick Artiola, Ian L. Pepper, Mark 1. Brusseau, (2004). Environmental monitoring and characterization, Elsevier Science \& 
Technology

Books,

ISBN:

0120644770,pp:1-8.11,12,29,30,86

8) Jorge A. Delgado; Ronald F. Follett,(2010). Advanced in nitrogen management for water quality,Chapter 1, Environmental and Human impacts of reactive Nitrogen,ISBN: 978-0-9769432-0-4,pages 10,11.

9) J. L. Hatfield; R. F. Follett, (2008).Nitrogen in the environment :sources, problems and management, second edition.ISBN-13:9780-12-374347-3, pages 35-36

10) K.M. Foley, A.R. Doniger, C.C. Shock, D.A. Horneck, and T.K. Welch. 2012. Nitrate Pollution in Groundwater: A Grower's Guide, Sustainable Agriculture Techniques, Oregon State University, Department of Crop and Soil Science Ext/CrS 137

11) M. Dumitru, C. Simona and I. Calciu, (2013). Managementul nutrientilol ,Directiva Nitrati, Descrierea CIP a Bibliotecii Naţionale a României MIHAIL, DUMITRU. ISBN 978-973-729-381-7

12) Romanian directive (LEGE $\mathrm{nr} .458$ din 8 iulie 2002), http://www.spcin.ro/uploads/4/8/5/8/485867 91/lege 458_08.07.2002

13) United Nations Conference on Environment and Development (UNCED), (1992). Earth Summit, Rio de Janeiro, Brazil 3-14 June 1992. 
International Journal of Engineering Applied Sciences and Technology, 2019

Vol. 4, Issue 2, ISSN No. 2455-2143, Pages 24-33

Published Online June 2019 in IJEAST (http://www.ijeast.com) 